Jpn. J. Hosp. Pharm.

16(5) 301-306 (1990)

\title{
Evaluation of Dose of Unstable Drug Administered by Infusion
}

\author{
TAKASHI MIZUMa ${ }^{\dagger 1,2}$, SAYURI NAKaJIMA ${ }^{\dagger 2}$, HiROSHI TAKASE ${ }^{\dagger 2}$, \\ MICHIYO KOMORI ${ }^{\dagger 2}$, TERUAKI NAKAGAWA ${ }^{\dagger 2}$ and ISAMU HORIKOSHI ${ }^{\dagger 2}$ \\ Department of Biopharmaceutics, 'Tokyo College of Pharmacy ${ }^{\dagger 1}$ \\ Department of Hospital Pharmacy, Toyama Medical \& Pharmaceutical University ${ }^{\dagger 2}$
}

(Received April 23, 1990)

Keywords - estimation of dose; unstable drug; intravenous infusion; simulation study; optimal dosage; infusion time; dosage regimen

\section{Introduction}

For the performance of optimal administration of drugs to patients, quantity as well as quality of drugs must be preserved until the end of administration of drug to patients although a dosage regimen is required as well. However, it sometimes can not be performed completely in the administration by infusion. For example, antibiotics, vitamines, peptide hormones, or proteins dissolved in solutions are influenced by $\mathrm{pH}$ of solution, temperature, light, or dilution of drug to lose pharmacological activity of drug or drug itself because of degradation, isomerization, or irreversible conformational change of drugs. Such qualitative and/or quantitative losses of drugs during infusion result in decrease of real effective amount of drug administrered to patients and affect the dosage regimen. In such case, we must recognize such losses of drugs. In the present simulation study, we tried to evaluate the dose of unstable drugs in solutions administered to patients by infusion and proposed the maximum infusion time of an unstable drug in a single preparation of the solution.

\section{Methods}

\section{Estimation of dose administered by infusion}

Let time and drug concentration in solution for infusion be 0 and $\mathrm{C}_{0}$, respectively, at the time when the drug solution was prepared.

Infusion rate of drug (amount/time), $\mathrm{R}_{\mathrm{in}}$, is expressed by

$$
\mathrm{R}_{\mathrm{in}}=\mathrm{C}_{\mathrm{t}} \times \mathrm{F}
$$

where $\mathrm{C}_{\mathrm{t}}$ and $\mathrm{F}$ is drug concentration (mass/volume or unit/volume) in solution at time $\mathrm{t}$ after preparation of drug solution and flow rate of drug solution (volume/time), respectively. Therefore, the dose $\left(\mathrm{x}_{\mathrm{T}}\right)$ ad-

†1 現所属: 東京都八王子市堀之内1432-1；1432-1, Horinouchi, Hachioji, Tokyo, 192-03 Japan

†2 富山市杉谷2630; 2630, Sugitani, Toyama, 930-01 Japan 
ministered by infusion from time $\mathrm{T}_{0}$ to time $\mathrm{T}_{\mathrm{z}}$ is obtained as follows.

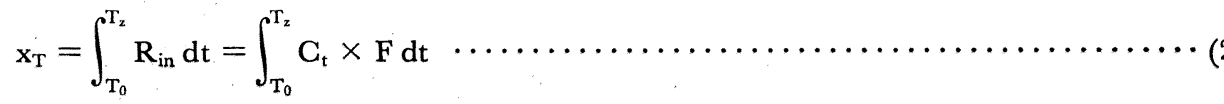

$$
\begin{aligned}
& \text { or } \\
& =\int_{T_{0}}^{T_{z}} f(t) \times F d t
\end{aligned}
$$

where $f(t)$ is the function of drug concentration in solution for infusion with time $t$ and is equal to $C_{t}$, that is, $f(t)=C_{t}$.

Assuming that no change of drug occur after preparation of drug solution for infusion, the dose $\left(\mathrm{X}_{\mathrm{T}}\right)$ administered by infusion from time $T_{0}$ to time $T_{z}$ is

$$
\mathrm{X}_{\mathrm{T}}=\int_{\mathrm{T}_{0}}^{\mathrm{T}_{z}} \mathrm{C}_{0} \times \mathrm{Fdt}
$$

The ratio, $\mathrm{x}_{\mathrm{T}} / \mathrm{X}_{\mathrm{T}}$, as an indicator for the evaluation of efficiency of dose of the unstable drug administered by infusion, is estimated as follows.

$$
\begin{aligned}
\mathbf{x}_{\mathrm{T}} / \mathrm{X}_{\mathrm{T}} & =\int_{\mathrm{T}_{0}}^{\mathrm{T}_{z}} \mathrm{C}_{\mathrm{t}} \times \mathrm{Fdt} / \int_{\mathrm{T}_{0}}^{\mathrm{T}_{z}} \mathrm{C}_{0} \times \mathrm{Fdt} \\
& =\int_{\mathrm{T}_{0}}^{\mathrm{T}_{z}} \mathrm{C}_{\mathrm{t}} \mathrm{dt} / \int_{\mathrm{T}_{0}}^{\mathrm{T}_{z}} \mathrm{C}_{0} \mathrm{dt} \cdots \cdots
\end{aligned}
$$

or

$$
\begin{aligned}
& =\int_{T_{0}}^{T_{z}} f(t) \times F d t / \int_{T_{0}}^{T_{z}} C_{0} \times F d t \\
& =\int_{T_{0}}^{T_{z}} f(t) d t / \int_{T_{0}}^{T_{z}} C_{0} d t \cdots \cdots \cdots
\end{aligned}
$$

We call the ratio $x_{T} / X_{T}$, defined by eq. (4-a) and (4-b), the Fraction of Efficiency of Dose (FED). Equations (4-a) and (4-b) indicate that FED, $x_{\mathrm{T}} / \mathrm{X}_{\mathrm{T}}$, which means the fraction of efficiency of "real dose" administered against the dose assuming no change in drug solution after preparation for infusion, can be calculated by the AUC (Area Under the Curve) of drug concentration in solution from time $\mathrm{T}_{0}$ (start time of infusion) to $T_{z}$ (stop time of infusion) and the AUC obtained by $\mathrm{C}_{0} \times\left(\mathrm{T}_{z}-\mathrm{T}_{0}\right)$. That is,

$$
\mathrm{x}_{\mathrm{T}} / \mathrm{X}_{\mathrm{T}}=\mathrm{AUC}_{\mathrm{T}_{0}}^{\mathrm{T}_{2}} /\left\{\mathrm{C}_{0} \times\left(\mathrm{T}_{\mathrm{z}}-\mathrm{T}_{0}\right)\right\}
$$

\section{Because}

$$
\begin{aligned}
\int_{T_{0}}^{T_{z}} C_{0} d t & =\left[C_{0} \times t\right]_{T_{0}}^{T_{z}} \\
& =C_{0} \times\left(T_{z}-T_{0}\right)
\end{aligned}
$$

Assuming that preparation time (time 0 ) of drug solution is equal to the start time $\left(\mathrm{T}_{0}\right)$ of infusion, or that the loss of drug after degradation or inactivation during infusion time $\left(T_{z}-T_{0}\right)$ is much less and negligible compared to the amount of drug prepared at time 0 and, thereby, $T_{0}=0$, equation (5) can be simplified to 


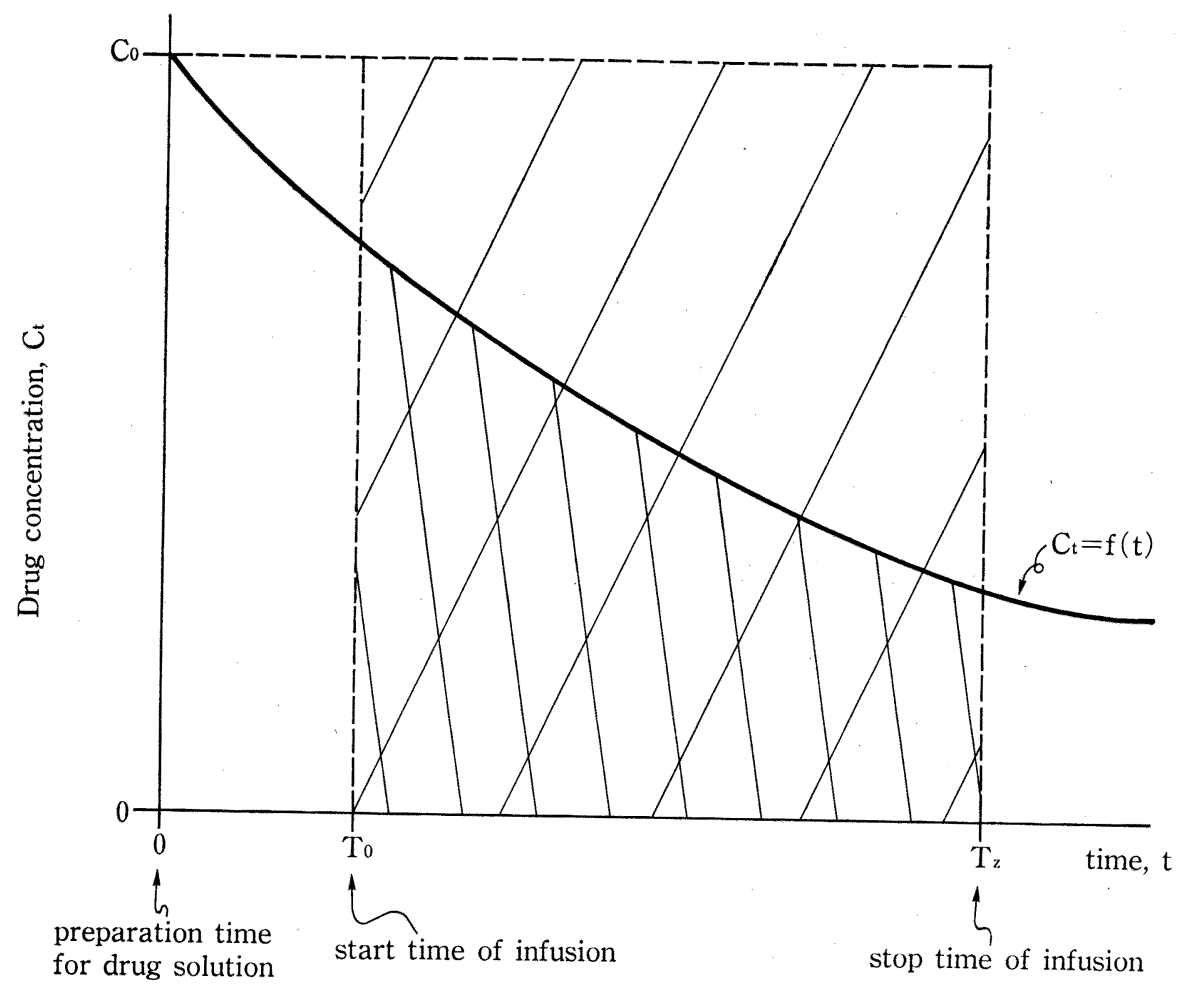

Fig. 1. The Concentration Versus Time Curve of Unstable Drug during Infusion. The area indicated with $\square$ represents the value of $\int_{T_{0}}^{T_{z}} C_{t} d t$. The area indicated with $Z / \triangle$ represents the value of $\int_{\mathrm{T}_{0}}^{\mathrm{T}_{2}} \mathrm{C}_{0} \mathrm{dt}$.

the following eq. (6).

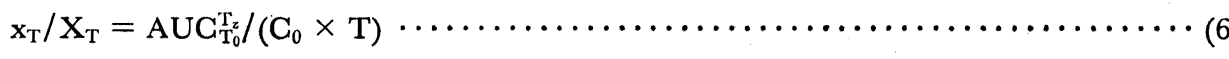

$$
\begin{aligned}
& \text { or } \\
& =\int_{0}^{\mathrm{T}} \mathrm{C}_{\mathrm{t}} \mathrm{dt} / \int_{0}^{\mathrm{T}} \mathrm{C}_{0} \mathrm{dt}
\end{aligned}
$$

where $T=T_{z}-T_{0}$.

The FED, $x_{T} / X_{T}$, in the case that the degradation or the inactivation of drug is followed by zero or first-order rate reaction, can be estimated by eq. (6-b) as follows.

a) When the concentration-time curve is followed by zero-order or pseudo zero-order rate, the concentration of drug at time $t$ may be expressed by

$$
C_{t}=f(t)=-k_{0} \times t+C_{0}
$$

where $\mathrm{k}_{0}$ represents zero-order rate constant. Therefore, from eq. (6-b)

$$
\mathrm{x}_{\mathrm{T}} / \mathrm{X}_{\mathrm{T}}=\int_{0}^{\mathrm{T}}\left(-\mathrm{k}_{0} \times \mathrm{t}+\mathrm{C}_{0}\right) \mathrm{dt} / \int_{0}^{\mathrm{T}} \mathrm{C}_{0} \mathrm{dt}
$$




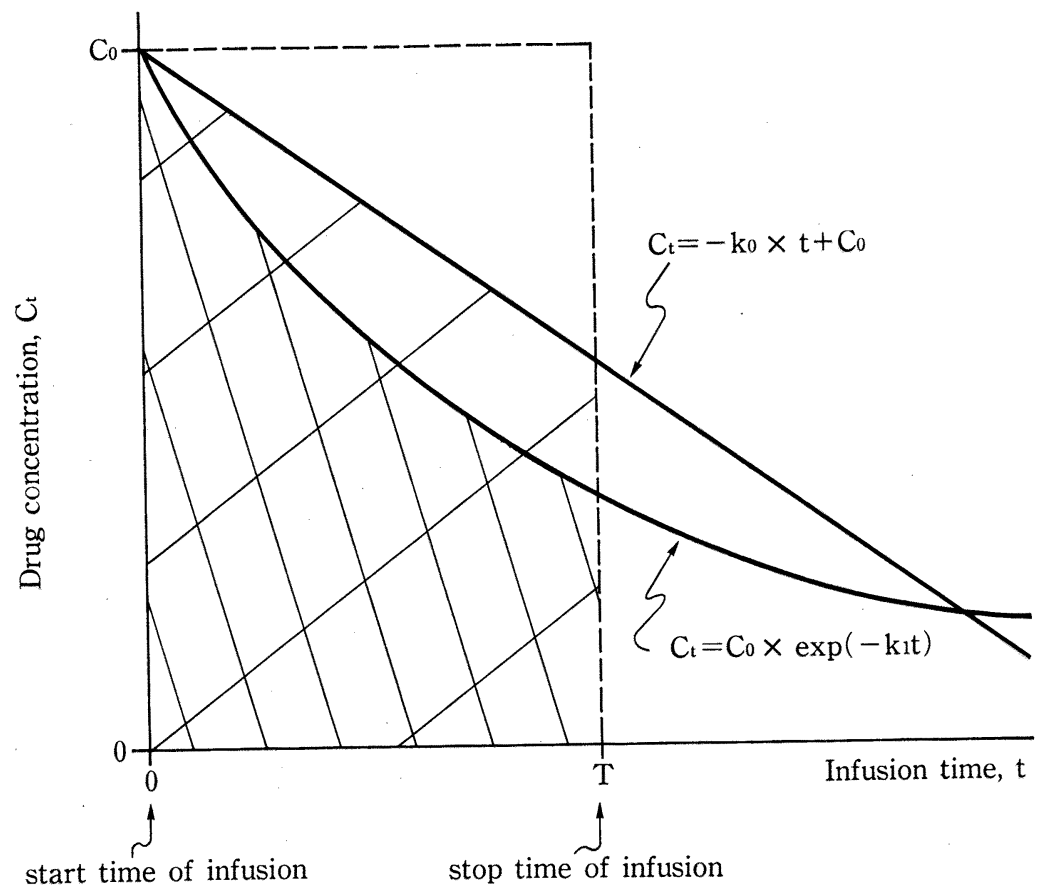

Fig. 2. The Concentration Versus Time Curve of Unstable Drug during Infusion. The area indicated with $\nabla Z \triangle$ represents the value of $\int_{0}^{\mathrm{T}}\left(-\mathrm{k}_{0} \times \mathrm{t}+\mathrm{C}_{0}\right) \mathrm{dt}$. The area indicated with $\square \otimes$ represents the value of $\int_{0}^{\mathrm{T}}\left(\mathrm{C}_{0} \times \exp \left(-\mathrm{k}_{1} \cdot \mathrm{t}\right)\right) \mathrm{dt}$.

$$
\begin{aligned}
& =\left[-\mathrm{k}_{0} \times \mathrm{t}^{2} / 2+\mathrm{C}_{0} \times \mathrm{t}\right]_{0}^{\mathrm{T}} /\left[\mathrm{C}_{0} \times \mathrm{t}\right]_{0}^{\mathrm{T}} \\
& =\left(-\mathrm{k}_{0} \times \mathrm{T}\right) /\left(2 \times \mathrm{C}_{0}\right)+1 \cdots \cdots \cdots \\
& =-\left(\mathrm{C}_{0}-\mathrm{C}_{\mathrm{T}}\right) /\left(2 \times \mathrm{C}_{0}\right)+1 \\
& =\left(\mathrm{C}_{\mathrm{T}} / \mathrm{C}_{0}+1\right) / 2 \cdots \cdots \cdots \cdots \cdots \cdots
\end{aligned}
$$

where $\mathrm{k}_{0} \times \mathrm{T}=\mathrm{C}_{0}-\mathrm{C}_{\mathrm{T}}$ because eq. (7) may represents $\mathrm{C}_{\mathrm{T}}=-\mathrm{k}_{0} \times \mathrm{T}+\mathrm{G}_{0}$ when $\mathrm{t}=\mathrm{T}$.

Equation (9) represents that $\mathrm{FED}, \mathrm{x}_{\mathrm{T}} / \mathrm{X}_{\mathrm{T}}$, can be obtained with the value of remaining ratio $\left(\mathrm{C}_{\mathrm{T}} / \mathrm{C}_{0}\right)$. In Table 1 , the relationships among infusion time $(\mathrm{T})$, remaining ratio $\left(\mathrm{C}_{\mathrm{T}} / \mathrm{C}_{0}\right)$, and the $\mathrm{FED}$ $\left(\mathrm{x}_{\mathrm{T}} / \mathrm{X}_{\mathrm{T}}\right)$ are shown.

b) When the concentration-time curve is followed by first-order or pseudo first-order rate, the drug concentration at time $t$ may be expressed by

$$
\mathrm{C}_{\mathrm{t}}=\mathrm{f}(\mathrm{t})=\mathrm{C}_{0} \exp \left(-\mathrm{k}_{1} \times \mathrm{t}\right)
$$

where $k_{1}$ is first-order rate constant. Therefore,

$$
\begin{aligned}
\mathrm{x}_{\mathrm{T}} / \mathrm{X}_{\mathrm{T}} & =\int_{0}^{\mathrm{T}}\left\{\mathrm{C}_{0} \exp \left(-\mathrm{k}_{1} \times \mathrm{t}\right)\right\} \mathrm{dt} / \int_{0}^{\mathrm{T}} \mathrm{C}_{0} \mathrm{dt} \\
& =\left[-\exp \left(-\mathrm{k}_{1} \times \mathrm{t}\right) / \mathrm{k}_{1}\right]_{0}^{\mathrm{T}} /\left[\mathrm{C}_{0} \times \mathrm{t}\right]_{0}^{\mathrm{T}}
\end{aligned}
$$


Table 1. Relationships among Infusion Time, Remaining Ratio $\left(\mathrm{C}_{\mathrm{T}} / \mathrm{C}_{0}\right)$, and FED $\left(\mathrm{x}_{\mathrm{T}} / \mathrm{X}_{\mathrm{T}}\right)$ of Unstable Drug Followed by Zero-order Rate.

\begin{tabular}{|ccc|}
\hline Time & $\begin{array}{c}(\%) \\
\mathrm{C}_{\mathrm{T}} / \mathrm{C}_{0}\end{array}$ & $\begin{array}{c}(\%) \\
\mathrm{x}_{\mathrm{T}} / \mathrm{X}_{\mathrm{T}}\end{array}$ \\
\hline $0.05 \mathrm{C}_{0} / \mathrm{k}_{0}$ & 95.0 & 97.5 \\
$0.1 \mathrm{G}_{0} / \mathrm{k}_{0}$ & 90.0 & 95.0 \\
$0.2 \mathrm{G}_{0} / \mathrm{k}_{0}$ & 80.0 & 90.0 \\
$0.3 \mathrm{C}_{0} / \mathrm{k}_{0}$ & 70.0 & 85.0 \\
$0.4 \mathrm{C}_{0} / \mathrm{k}_{0}$ & 60.0 & 80.0 \\
$0.5 \mathrm{C}_{0} / \mathrm{k}_{0}$ & 50.0 & 75.0 \\
$0.6 \mathrm{C}_{0} / \mathrm{k}_{0}$ & 40.0 & 70.0 \\
$0.8 \mathrm{C}_{0} / \mathrm{k}_{0}$ & 20.0 & 60.0 \\
$\mathrm{C}_{0} / \mathrm{k}_{0}$ & 0.0 & 50.0 \\
\hline
\end{tabular}

Table 2. Relationships among Infusion Time, Remaining Ratio $\left(\mathrm{C}_{\mathrm{T}} / \mathrm{C}_{0}\right)$, and $\mathrm{FED}$ $\left(\mathrm{x}_{\mathrm{T}} / \mathrm{X}_{\mathrm{T}}\right)$ of Unstable Drug Followed by Zero-order Rate.

\begin{tabular}{|lcc|}
\hline \multicolumn{1}{|c}{ Time } & $\begin{array}{c}(\%) \\
\mathrm{C}_{\mathrm{T}} / \mathrm{C}_{0}\end{array}$ & $\begin{array}{c}(\%) \\
\mathrm{x}_{\mathrm{T}} / \mathrm{X}_{\mathrm{T}}\end{array}$ \\
\hline $0.0513 / \mathrm{k}_{1}$ & 95.0 & 97.5 \\
$0.103 / \mathrm{k}_{1}$ & 90.2 & 95.0 \\
$0.105 / \mathrm{k}_{1}$ & 90.0 & 94.9 \\
$0.214 / \mathrm{k}_{1}$ & 80.7 & 90.0 \\
$0.223 / \mathrm{k}_{1}$ & 80.0 & 89.6 \\
$0.357 / \mathrm{k}_{1}$ & 70.0 & 84.1 \\
$0.464 / \mathrm{k}_{1}$ & 62.9 & 80.0 \\
$0.511 / \mathrm{k}_{1}$ & 60.0 & 78.3 \\
$0.693 / \mathrm{k}_{1}$ & 50.0 & 72.1 \\
$\left(\mathrm{t}_{1 / 2}\right)$ & & \\
$0.761 / \mathrm{k}_{1}$ & 46.7 & 70.0 \\
$1.126 / \mathrm{k}_{1}$ & 32.4 & 60.0 \\
$1.594 / \mathrm{k}_{1}$ & 20.3 & 50.0 \\
\hline
\end{tabular}

$$
\begin{aligned}
& =\left\{\mathrm{C}_{0} \times\left(1-\exp \left(-\mathrm{k}_{1} \times \mathrm{T}\right)\right) / \mathrm{k}_{1}\right\} /\left(\mathrm{C}_{0} \times \mathrm{T}\right) \\
& =\left\{1-\exp \left(-\mathrm{k}_{1} \times \mathrm{T}\right)\right\} /\left(\mathrm{k}_{1} \times \mathrm{T}\right) \cdots \cdots \cdots
\end{aligned}
$$

From eq. (10) and (11), the relationships among infusion time $(\mathrm{T})$, remaining ratio $\left(\mathrm{C}_{\mathrm{T}} / \mathrm{C}_{0}\right)$, and the FED $\left(x_{T} / X_{T}\right)$ can be obtained using a microcomputer (Table 2).

\section{Results and Discussion}

In order to evaluate the "real" dose of unstable drug administered by infusion, we defined the fraction of efficiency of dose (FED), $\mathrm{x}_{\mathrm{T}} / \mathrm{X}_{\mathrm{T}}$, which represents the ratio of the "real" dose administered by infusion to the "ideal" dose administered by infusion, where "ideal" means no change of concentration of drug solution. FED $\left(x_{T} / X_{T}\right)$ which can be obtained by eq. (4-a) or eq. (4-b), represents the ratio of the area $(\square \otimes)$ under the curve of concentration of drug in solution for infusion from time $T_{0}$ to time $T_{z}$ to the area $(R / \triangle)$ under the curve of $C_{t}=C_{0}$ from time $T_{0}$ to time $T_{z}$ (Fig. 1).

$\operatorname{FED}\left(\mathrm{x}_{\mathrm{T}} / \mathrm{X}_{\mathrm{T}}\right)$ can be obtained by eq. (6-b) when preparation time may be equal to start time of infusion in such cases as described in METHODS (Fig. 2). When the concentration-time curve is followed by zero-order rate under conditions in the case described, the relationships among infusion time (T), remaining ratio $\left(\mathrm{C}_{\mathrm{T}} / \mathrm{C}_{0}\right)$, and $\mathrm{FED}\left(\mathrm{x}_{\mathrm{T}} / \mathrm{X}_{\mathrm{T}}\right)$ were obtained as in Table 1. FED $\left(\mathrm{x}_{\mathrm{T}} / \mathrm{X}_{\mathrm{T}}\right)$ after any time of infusion (T) was obviously shown to be greater than remaining ratio $\left(\mathrm{C}_{\mathrm{T}} / \mathrm{C}_{0}\right)$. For example, FED is $95 \%$ after $0.1 \mathrm{C}_{0} / \mathrm{k}_{0}$ of infusion time at which time remaining ratio is $90 \%$. Even if remaining ratio decreases to $50 \%$, FED still remains $75 \%$. Table 1 tells us that once drug solution is prepared for infusion, the infusion should be completed within the time of $0.2 \mathrm{C}_{0} / \mathrm{k}_{0}$ when $\mathrm{FED}$ is required more than $90 \%$ of "ideal" dose, where $\mathrm{k}_{0}$ may be obtained by experiment in advance under the same condition as the infusion. 
When the concentration-time curve is followed by first-order rate under the conditions in the case described before, the relationships among infusion time $(T)$, remaining ratio $\left(\mathrm{C}_{\mathrm{T}} / \mathrm{C}_{0}\right)$, and $\mathrm{FED}\left(\mathrm{x}_{\mathrm{T}} / \mathrm{X}_{\mathrm{T}}\right)$ were obtained by eq. (6-b) as in Table 2. FED $\left(\mathrm{x}_{\mathrm{T}} / \mathrm{X}_{\mathrm{T}}\right)$ after any time of infusion $(\mathrm{T})$ was obviously shown to be greater than remaining ratio $\left(\mathrm{C}_{\mathrm{T}} / \mathrm{C}_{0}\right)$ as well as those shown in Table 1 . For example, FED is $94.9 \%$ after $0.105 / k_{1}$ of infusion time at which time remaining ratio is $90 \%$. Even if remaining ratio decreases to $50 \%$, FED still remains $72.1 \%$. Table 2 also tells us that once drug solution is prepared for infusion, the infusion should be completed within the time of $0.214 / \mathrm{k}_{1}$ when FED is required more than $90 \%$ of ideal dose, where $k_{1}$ may be obtained by experiment in advance under the same condition as the infusion.

Using eq. (6-b) and experimental data of remaining ratio versus time, we could also evaluate the dose of the photo-unstable drug administered by infusion ${ }^{1)}$.

In summary, by defining the fraction of efficiency of dose (FED), which is a ratio of "real" dose to "ideal" dose administered by infusion, versus infusion time and by calculation of FED with a microcomputer, the dose of the unstable drug administered by infusion could be evaluated. In either case that the concentration-time curve is followed by zero-order or first-order, FED is remained about $95 \%$ and about $90 \%$ after the infusion time when remaining ratio is $90 \%$ and $80 \%$, respectively. It is recommended that once solution of drug, which concentration is decreased by zero-order or first-order rate, is prepared for infusion, the infusion should be completed within the time of $0.2 \mathrm{C}_{0} / \mathrm{k}_{0}$ or $0.214 / \mathrm{k}_{1}$ when FEDs are required more than $90 \%$ of ideal dose. Finally, it is noted that results obtained in the present report can be applied to drugs which are not converted to toxic compounds by degradation, isomerization, or irreversible conformational change.

\section{Reference}

1) T. Mizuma, S. Nakajima, H. Takase, M. Komori, T. Nakagawa and I. Horikoshi, Jpn. J. Hospital Pharmacy, 16(3), 205-210 (1990). 